\title{
Rituximab reduces anti-cardiolipin levels in patients with systemic lupus erythematosus
}

\author{
R Martínez-Pérez ${ }^{1 *}$, A Muñoz-Jiménez ${ }^{1}, S_{\text {S Rodríguez-Montero }}{ }^{1}$, A Fernández-Nebro ${ }^{2}, L_{\text {Carreño }}^{3}, J$ L Marenco ${ }^{1}$ \\ From 5th European Workshop on Immune-Mediated Inflammatory Diseases \\ Sitges-Barcelona, Spain. 1-3 December 2010
}

\section{Introduction}

Patients with systemic lupus erythematosus (SLE), can produce antibodies directed against the complex phospholipds- $\beta$-glycoprotein 1 . Rituximab is an antibody directed to most B-cells, except precursors and mature plasma cells. It can produce reductions in antibody titers.

We have treated SLE patients refractory to conventional immunosuppressive therapy, with Rituximab and we searched for a reduction in anticardiolipin autoantibodies.

\section{Material and methods}

We have performed an observational, retrospective and multicentric study from 3 Spanish hospitals. We analysed 46 patients with complex clinical index (SLEDAI, physician global assessment scale) and laboratory determinations, included anticardiolipin levels, at start, week 24 and final visit.

\section{Results}

We have treated 46 patients, 3 men and 43 women, 91.3\% Caucasians. Antiphospholipid syndrome was present in 14 patients (30.4\%). A Lupus Anticoagulant (LA) was detected in $42.9 \%$.

40 patients received the dose for arthritis $(2 \times 1 \mathrm{~g})$ and $4 \times 375 \mathrm{mg} / \mathrm{m} 2$ in the others. The mean of cycles used was $2(1-3)$.

After the Rituximab therapy the LA was positive in only $10 \%(\mathrm{p}<0.05)$. Anticardiolipin levels were reduced too, IgG aCL showed a significant reduction from 8.57 $\mathrm{UI}(3.44,53.20)$ to $5.93 \mathrm{UI}(1.70,40.50), \mathrm{p}<0.002$. A non significant reduction in IgM aCL was detected $4.61 \mathrm{UI}$ $(2,19.6)$ to $2.75(1.02,6.3)$. We have not detected new thrombotic events after Rituximab therapy.

${ }^{1}$ Rheumatology Unit, Valme University Hospital, Seville, Spain

Full list of author information is available at the end of the article

\section{Discussion}

We have observed a reduction in the anticardiolipin antibody titers and LA among SLE patients treated with Rituximab. No new thrombotic episodes were observed after treatment with a mean follow-up of 21.1 months. We think may be necessary a longer follow-up to decide a possible efficacy for Rituximab in the management or antiophospholipid syndrome.

In spite of the absence of significant improvement of patient in the EXPLORE study, an analysis by Tew, shows a reduction of anticardiolipin antibodies levels to near normal. A bibliographic search for similar studies has not yield other results.

\section{Author details}

${ }^{1}$ Rheumatology Unit, Valme University Hospital, Seville, Spain. ${ }^{2}$ Rheumatology Unit, Malaga Civil Hospital, Malaga, Spain. ${ }^{3}$ Rheumatology Unit, Gregorio Marañón University Hospital, Madrid, Spain.

Published: 25 November 2010

doi:10.1186/1479-5876-8-S1-P69

Cite this article as: Martínez-Pérez et al:: Rituximab reduces anti-

cardiolipin levels in patients with systemic lupus erythematosus. Journal of Translational Medicine 2010 8(Suppl 1):P69.

Submit your next manuscript to BioMed Central and take full advantage of:

- Convenient online submission

- Thorough peer review

- No space constraints or color figure charges

- Immediate publication on acceptance

- Inclusion in PubMed, CAS, Scopus and Google Scholar

- Research which is freely available for redistribution 